\title{
Exogenous carbohydrases do not improve the physiological and meat quality parameters of female Japanese quail fed canola-based diets
}

\author{
C.M. Mnisi ${ }^{\sharp 1,2}$, V. Mlambo ${ }^{1,2}$, K.G.G. Phatudi ${ }^{1,2}$ \& T.B. Matshogo ${ }^{1,2}$ \\ ${ }^{1}$ Department of Animal Science, Faculty of Natural and Agricultural Sciences, North-West University, P Bag x2046, \\ Mmabatho 2735, Mafikeng, South Africa \\ ${ }^{2}$ Food Security and Safety Niche area, Faculty of Natural and Agricultural Sciences, North-West University, P Bag x2046, \\ Mmabatho, 2735, South Africa
}

(Received 8 September 2017; Accepted 5 October 2017; First published online 17 October 2017)

\begin{abstract}
Copyright resides with the authors in terms of the Creative Commons Attribution 4.0 South African Licence.
See: http://creativecommons.org/licenses/by/4.0/za

Condition of use: The user may copy, distribute, transmit and adapt the work, but must recognise the authors and the South African Journal of Animal Science.
\end{abstract}

\begin{abstract}
In an internally controlled environment, a feeding trial using 210 six-week-old female Japanese quail (189.63 $\pm 11.891 \mathrm{~g}$ liveweight) was conducted to evaluate the effect of carbohydrase-treated (endo-1.4-betaxylanase $5600 \mathrm{TXU} / \mathrm{g}$ and endo-1.4-beta-glucanase $2500 \mathrm{TGU} / \mathrm{g}$ ) canola-based diets on growth performance, haemo-biochemical parameters, carcass characteristics, and meat quality traits. Five isocaloric and isonitrogenous experimental diets were formulated: the control diet (CON) (commercial growers diet with no canola meal (CM) included); the control diet in which $17.5 \%$ of soybean meal was replaced with $\mathrm{CM}$ (CM0); and the CM0 diet in which a carbohydrase multi-enzyme was added at a rate of $5 \%, 10 \%$ and $15 \%$ (CM50, CM100 and CM150, respectively). Diets and clean water were offered ad libitum during the fourweek experimental period. Average weekly feed intake (AWFI) and average weekly weight gain (AWG) were used to calculate feed conversion efficiency (FCE). In week 7, no dietary influence was observed on AWFI. In week 8 and week 9, CON stimulated lower AWFI compared with diet CM100. Diets had no significant influence on AWG, FCE, and haemo-biochemical parameters of Japanese quail. Adding carbohydrases had no significant effect on internal organs, carcass and meat quality traits of quail. It was therefore concluded that inclusion of exogenous carbohydrases alone did not improve the utilization of a canola meal-based quail diet. However, there is a possibility that utilization of higher canola levels would be enhanced through multienzyme combinations.
\end{abstract}

Keywords: Blood parameters, carcass traits, exogenous enzymes, growth, soybean meal

\#Corresponding author: mnisiecm@gmail.com

\section{Introduction}

Coturnix coturnix japonica, commonly known as Japanese quail, is a strain of birds that are noted for their high growth rate, early sexual maturity and market age, short generation intervals and resistance to several avian diseases (Kabir, 2004; Deka \& Borah, 2008; Dauda et al., 2014; Mnisi et al., 2017). In countries such as Japan, India, and France and in most parts of southern Africa, quail farming is gaining attention from farmers, entrepreneurs and researchers (Minvielle, 2004; Dauda et al., 2014) because it is economically viable, and can be an alternative source of animal protein for human consumption (Puspamitra et al., 2014). However, feed costs, which constitute about $80 \%$ of total cost of production, remain a major challenge in poultry farming owing to the use of expensive feed ingredients during feed formulation (Elagib et al., 2013). Soybean and full-fat soybean products are commonly used to provide high-quality protein (Woyengo et al., 2014; Beski et al., 2015; Vagadia et al., 2017) for quail. However, the demand for soybean on the world market is high owing to competition between human beings and animals for this dietary protein source (Mnisi \& Mlambo, 2017). The resultant higher market prices of soybean suggest that it is prudent to search for less expensive alternatives to this ingredient in quail diets. A possible candidate is canola meal (CM), a by-product of oil extraction, with a protein content ranging from 36\% to 39\% (Wickramasuriya et al., 2015). However, canola contains anti-nutritional factors that are known to restrict its utilization in the poultry industry. Secondary plant compounds such as glucosinolates, erucic acid, phytic acid, non-starch polysaccharides (NSP), and high fibre content limit the value of canola as a major protein source in quail feed formulation. Several scholars have reported that canola is a potential protein source, but inclusion levels greater than $250 \mathrm{~g} / \mathrm{kg}$ can cause detrimental effects and reduce performance in birds (Naseem et al., 
2006; Ahmad et al., 2007; Min et al., 2011). A recent report by Mnisi \& Mlambo (2017) indicated that CM could be used to replace $12.5 \%$ soybean in female Japanese quail diets without compromising growth performance, health, and quality of meat. However, in the same study, increasing the canola inclusion level to $17.5 \%$ of soybean resulted in a reduction in feed intake. The application of exogenous enzymes to complement endogenous digestive enzymes of quail may increase the utilization and digestibility of CM (Cowieson \& Bedford, 2009). Carbohydrases hydrolyse cell wall polysaccharides in canola such as pentosans and $\beta$-glucans (NSPs), and therefore reduce their encapsulating effect, resulting in enhanced availability of carbohydrates, proteins and other nutrients (Campbell \& Bedford, 1992; Khajali \& Slominski, 2012). Additionally, the inclusion of carbohydrases in other poultry species has been reported to increase nutrient bioavailability and improve bird performance (Choct, 2006; Romero et al., 2013). Other beneficial effects of carbohydrases include modulation of intestinal microflora (Fernández et al., 2000), augmentation of digestive enzymes in growing animals (Gracia et al., 2003), improved access of endogenous enzymes to cell contents (Cowieson, 2005), and reduction of endogenous amino acid losses (Gao et al., 2008; Cowieson \& Bedford, 2009). The effectiveness of exogenous carbohydrases in quail diets is largely unknown because most research is focused on broiler nutrition. This study was therefore designed to investigate the effects of treating canola-based diets with graded levels of a carbohydrase on growth performance, haemobiochemical parameters, carcass and meat quality traits of Japanese quail. The authors hypothesized that adding a carbohydrase multi-enzyme (endo-1.4-beta-xylanase ( $>1-<3 \% ; 5600 \mathrm{TXU} / \mathrm{g}$, EC no. 232-800-2) and endo-1.4-beta-glucanase (>0.3-<1\%; $2500 \mathrm{TGU/g}$, EC no. 232-734-4) mixture to canola-based diets would improve growth response, haemo-biochemical parameters, carcass characteristics, and meat quality traits of female Japanese quail.

\section{Materials and methods}

The procedures used to rear and slaughter quail were reviewed and approved by the Animal Research Ethics Committee, North-West University (AREC-MC) (approval no. NWU-00521-16-A9). For the duration of the study, all efforts were made to ensure that the rearing of the Japanese quail complied with the guidelines for the care and use of research animals (South African Bureau of Standards, 2008).

The feeding experiment was conducted at Molelwane Farm of North-West University (25\%40.459' S, 26010.563' E), South Africa. Ambient temperature ranges between $27^{\circ} \mathrm{C}$ and $37^{\circ} \mathrm{C}$ in summer and between $-3{ }^{\circ} \mathrm{C}$ and $25^{\circ} \mathrm{C}$ in winter months, respectively. Annual rainfall ranges between 300 and $600 \mathrm{~mm}$. Canola meal was acquired from Southern Oil (Pty) Ltd (Western Cape, South Africa) while soybean meal (SBM) was supplied by Multi Agric (Edms) Bpk (North West, South Africa). According to the suppliers, both meals were solvent extracted. Carbohydrase enzyme mixture was received from BASF (Pty) Ltd (Gauteng, South Africa). This was a thermo-resistant NSP complex, containing endo-1.4-beta-xylanase $(>1-<3 \%$; $5600 \mathrm{TXU} / \mathrm{g}$, EC no. 232-800-2) and endo-1.4-beta-glucanase (>0.3-<1\%; $2500 \mathrm{TGU/g}$, EC no. 232-734-4).

Five isonitrogenous and isocaloric experimental diets (Table 1) were formulated using the Format ${ }^{\circledR}$ Software (Optifeeds (Pty) Ltd, Lichtenburg, South Africa): CON: control diet (commercial growers diet with no canola meal inclusion), CM0: control diet in which $17.5 \%$ of soybean meal was replaced with CM; CM50: CM0 diet in which a carbohydrase multi-enzyme was added at a rate of 5\%; CM100: CM0 diet in which a carbohydrase multi-enzyme was added at a rate of 10\%; and CM150: CM0 diet in which a carbohydrase multi-enzyme was added at a rate of $15 \%$. These inclusion levels were based on the recommended level suggested by the supplier $(0.1 \mathrm{~g} / \mathrm{kg}$ inclusion rate). However, this recommended application rate was for chickens. As a result, three inclusion levels were investigated for quail, namely one level below the recommended inclusion level and another above it.

These experimental diets were analysed according to AOAC (2005) for laboratory dry matter (DM) (AOAC method no. 930.15), organic matter (OM) (AOAC method no. 924.05). The total nitrogen content was determined by the standard macro-Kjeldahl method (N) (AOAC method no. 984.13) and was converted to crude protein by multiplying by a factor of 6.25 . Amino acids were determined by hydrolysing the diet samples with $6 \mathrm{M} \mathrm{HCl}$ (containing phenol) for 24 hours at $110 \pm 2{ }^{\circ} \mathrm{C}$ in glass tubes sealed under vacuum as described by Ravindran et al. (2005). Crude fibre (CF) was determined using the ANKOM ${ }^{2000}$ fibre analyser (ANKOM Technology, New York) according to Van Soest et al. (1991). Mineral matter was analysed according to Agri Laboratory Association of Southern Africa guidelines (AgriLASA, 1998). Metabolizable energy (ME) content was predicted using near infrared reflectance spectroscopy SpectraStar XL (Unity Scientific, Australia). 
Table 1 Gross composition $(\mathrm{g} / \mathrm{kg})$ of canola meal-based diets treated with a carbohydrase multi-enzyme

\begin{tabular}{|c|c|c|c|c|c|}
\hline & \multicolumn{5}{|c|}{ Diets $^{1}$} \\
\hline & CON & CMO & CM50 & CM100 & CM150 \\
\hline Carbohydrases & 0 & 0 & 0.05 & 0.1 & 0.15 \\
\hline Canola oilcake & 0 & 175 & 175 & 175 & 175 \\
\hline Yellow maize - fine & 698.6 & 595.1 & 595.1 & 595.1 & 595.1 \\
\hline Prime gluten 60 & 18.0 & 24.3 & 24.3 & 24.3 & 24.3 \\
\hline Full-fat soya meal & 50.7 & 174.0 & 174.0 & 174.0 & 174.0 \\
\hline Soybean meal & 196.7 & 0.0 & 0.0 & 0.0 & 0.0 \\
\hline Limestone powder & 14.5 & 12.2 & 12.2 & 12.2 & 12.2 \\
\hline Mono calcium phosphate & 7.2 & 5.6 & 5.6 & 5.6 & 5.6 \\
\hline Salt - fine & 3.2 & 3.2 & 3.2 & 3.2 & 3.2 \\
\hline Sodium bicarbonate & 1.7 & 1.6 & 1.6 & 1.6 & 1.6 \\
\hline Choline powder & 0.8 & 0.8 & 0.8 & 0.8 & 0.8 \\
\hline Lysine & 2.8 & 2.9 & 2.9 & 2.9 & 2.9 \\
\hline L-Threonine & 0.4 & 0.0 & 0.0 & 0.0 & 0.0 \\
\hline Methionine & 1.9 & 1.8 & 1.8 & 1.8 & 1.8 \\
\hline Grower - phytase & 1.7 & 1.7 & 1.7 & 1.7 & 1.7 \\
\hline Coxistac & 0.5 & 0.5 & 0.5 & 0.5 & 0.5 \\
\hline Olaquindox & 0.4 & 0.4 & 0.4 & 0.4 & 0.4 \\
\hline
\end{tabular}

'Diets: CON: control diet (commercial growers diet with no canola meal inclusion), CM0: control diet in which $17.5 \%$ of soybean meal was replaced with CM, CM50: CM0 diet in which a carbohydrase multi-enzyme was added at a rate of $5 \%$, CM100: CM0 diet in which a carbohydrase multi-enzyme was added at a rate of 10\%; and CM150: CM0 diet in which a carbohydrase multi-enzyme was added at a rate of $15 \%$

Three-week-old Japanese quail were purchased from a farm called Quail Breeders, Gauteng, South Africa. The quail were initially reared using a commercial grower-mash diet purchased from Optifeeds (Pty) Ltd (Lichtenburg, North West, South Africa) and had access to fresh water at all times. Quails were reared until five weeks old to allow differentiation of gender. At five weeks old, 210 female quail were selected and then randomly allocated to 30 replicate pens (experimental units), with each pen having seven quail. These pens were in a form of standing cages with four partitions. The sizes of the pens were $100 \mathrm{~cm}$ length $\times 60$ $\mathrm{cm}$ width $\times 30 \mathrm{~cm}$ height. The five experimental diets were randomly allocated to the pens $(6$ replicate pens per diet) and the quail were reared until they were nine weeks old. The quail were allowed to adapt to the pens and diets for a week before the experiment commenced.

Experimental diets and fresh water were provided ad libitum during the three-week experimental period. AWFI was calculated as the difference between the feed offered and the refusals collected the following morning before feeding. Quails were weighed weekly and AWG was calculated as follows:

Where: $\mathrm{t}_{0}=$ initial time (days)

$$
A D W G\left(t_{\circ}, T\right)=\frac{W(T)-W\left(t_{\mathrm{o}}\right)}{T-t_{\mathrm{o}}}
$$

$T=$ final time

$\mathrm{W}(\mathrm{T})=$ final bodyweight $(\mathrm{g})$

$\mathrm{W}\left(\mathrm{t}_{0}\right)=$ initial bodyweight $(\mathrm{g})$

Weekly feed conversion efficiency was calculated as weight gained divided by feed consumed.

At nine weeks old, quail stopped growing and were taken to Rooigrond Poultry Abattoir (North West, South Africa) for slaughter. At the abattoir, all the quail were live-hung upside down by their feet on a rail and electrically stunned. Quails were then slaughtered by cutting the jugular vein with a sharp knife and left 
hanging until bleeding stopped. After defeathering, quail were taken to the Animal Science Laboratory of North-West University to measure carcass characteristics, internal organs, and meat quality parameters.

At slaughter, about $4 \mathrm{~mL}$ of blood was collected from two quail randomly selected from each pen in two sets of sterilised tubes, one containing ethylene diamine tetra acetic acid as an anti-coagulant for haematology and the other without an anticoagulant for serum biochemical analysis. For haematology the tubes were stored in a cooler box with ice packs and for serum biochemistry, samples were stored at room temperature for a maximum of 45 minutes to clot and then refrigerated at $4{ }^{\circ} \mathrm{C}$ (Washington \& Van Hoosier, 2012). All analyses were conducted within 48 hours of collection (Buetow et al., 1999). Haematological parameters (erythrocytes, haemoglobin, haematocrit, leucocytes, lymphocytes, neutrophils and monocytes) were determined using an automated IDEXX LaserCyte Haematology Analyser (IDEXX Laboratories, Inc.). For serum biochemical analyses, amylase, glucose, lipase and triglycerides were analysed with an automated IDEXX vet test chemistry analyser (IDEXX Laboratories, Inc.).

The weights of the liver, cleaned gizzard, heart and length of small intestines were determined in the animal science laboratory. Hot carcass weight $(\mathrm{HCW})$ was recorded immediately after slaughter. After chilling for 24 hours, the carcasses were re-weighed to obtain the cold carcass weight (CCW). The dressing out percentage was determined as the proportion of HCW to slaughter weight.

Meat $\mathrm{pH}$ and temperature were recorded immediately after slaughter and also 24 hours post slaughter on the breast muscle (central area of the breast) using a Corning Model $4 \mathrm{pH}$-temperature meter (Corning Glass Works, Medfield, MA) equipped with an Ingold spear-type electrode (Ingold Messtechnik AG, Udorf, Switzerland) according to Stanford et al. (2003). After every 20 measurements, the pH meter was calibrated with $\mathrm{pH} 4$ and $\mathrm{pH} 7$ standard solutions (Ingold Messtechnik AG, Udorf, Switzerland) at a temperature of $2^{\circ} \mathrm{C}$.

Colour of the meat ( $L^{*}$ : lightness, $a^{*}$ : redness, and $b^{*}$ : yellowness) was determined using a Minolta colour-guide (BYK-Gardener GmbH, Geretsried, Germany), with a 20-mm diameter measurement area and illuminant D65-day light 10을 observation angle. The colour meter was calibrated using the green standard before measurements were taken. Colour recording was done in triplicate on the surface of a freshly cut slice of the breast muscle allowed to bloom for 1 hour on a polystyrene tray at $4{ }^{\circ} \mathrm{C}$. Hue angle was calculated as $\tan (\theta)=\frac{a^{*}}{b^{*}}$, and chroma was calculated as $\sqrt{a^{*^{2}+b^{* 2}}}$ as guided by Priolo et al. (2002).

After weighing, breast samples were placed in an oven set at $130{ }^{\circ} \mathrm{C}$ for 20 min to determine cooking losses. This formula was employed:

$$
\text { Cooking losses }(\%)=\frac{\text { initial weight }- \text { final weight }}{\text { initial weight }} \times 100
$$

After cooking, cylindrical samples (12.5 mm core diameter) of breast muscle was cored parallel to the grain of the meat, and sheared perpendicular to the fibre direction using a Warner Bratzler shear device mounted on a Universal Instron apparatus (crosshead speed $200 \mathrm{~mm} /$ minute, one shear in the centre of each core). The reported value represented the average peak force measurements of each sample in newtons.

All reported parameters were tested for normality using the NORMAL option in Proc Univariate statement before being subjected to analysis of variance. Weekly feed intake, weight gain and feed conversion efficiency data were analysed using repeated measure analysis (SAS, 2010). This statistical linear model was employed:

$$
Y_{i j k}=\mu+D_{i}+W_{j}+(D \times W)_{i j}+E_{i j k}
$$

Where: $Y_{i j k}=$ dependent variable

$\mu=$ population mean

$D_{i}=$ effect of diets

$W_{j=}$ effect of week

$(D \times W)_{i j}=$ effect of interaction between diets and week

$E_{i j k}=$ random error associated with observation ijk, assumed to be normally and independently distributed

Blood parameters, carcass characteristics and meat quality data were analysed using the GLM procedure of SAS version 9.4 (SAS, 2010). The linear statistical model was: 


$$
Y_{i k}=\mu+D_{i}+E_{i j}
$$

Where: $Y_{i j}=$ dependent variable

$\mu=$ population mean

$D_{i}=$ effect of diets

$E_{i k}=$ random error associated with observation $i j$, assumed to be normally and independently distributed

For all statistical tests, significance was declared at $P<0.05$. Least squares means (LSMEANS) were compared using the probability of difference option in the LSMEANS statement of SAS.

\section{Results}

All experimental diets were isocaloric and isonitrogenous, as indicated in Table 2. Inclusion of CM resulted in higher crude fibre and crude fat content of the diet. Canola-based diets tended to have higher phosphorus and methionine levels than the control diet, which did not include canola.

Table 2 Chemical composition ( $\mathrm{g} / \mathrm{kg}$, unless otherwise stated) of canola meal-based diets treated with a carbohydrase multi-enzyme

\begin{tabular}{lccccc}
\hline & \multicolumn{3}{c}{ 1 Diets } \\
\cline { 2 - 5 } & CON & CM0 & CM50 & CM100 & CM150 \\
\hline Proximate analysis & & & & & \\
Dry matter & 88.65 & 89.06 & 89.06 & 89.06 & 89.06 \\
${ }^{2}$ ME (MJ/kg) & 12.10 & 11.80 & 11.80 & 11.80 & 11.80 \\
Crude protein & 18.00 & 18.94 & 18.94 & 18.94 & 18.94 \\
Crude fat & 4.16 & 6.24 & 6.24 & 6.24 & 6.24 \\
Crude fibre & 2.32 & 4.18 & 4.18 & 4.18 & 4.18 \\
Mineral matter & & & & & \\
Calcium & 0.850 & 0.850 & 0.850 & 0.850 & 0.850 \\
Phosphorus & 0.497 & 0.563 & 0.563 & 0.563 & 0.563 \\
Sodium & 0.180 & 0.180 & 0.180 & 0.180 & 0.180 \\
Chlorine & 0.300 & 0.300 & 0.300 & 0.300 & 0.300 \\
Potassium & 0.763 & 0.733 & 0.733 & 0.733 & 0.733 \\
Amino acid profile & & & & & \\
Lysine & 1.079 & 1.110 & 1.110 & 1.110 & 1.110 \\
Methionine & 0.478 & 0.520 & 0.520 & 0.520 & 0.520 \\
Threonine & 0.705 & 0.733 & 0.733 & 0.733 & 0.733 \\
Tryptophan & 0.187 & 0.201 & 0.201 & 0.201 & 0.201 \\
Isoleucine & 0.739 & 0.750 & 0.750 & 0.750 & 0.750 \\
Arginine & 1.102 & 1.100 & 1.100 & 1.100 & 1.100 \\
Leucine & 1.692 & 1.728 & 1.728 & 1.728 & 1.728 \\
Valine & 0.844 & 0.908 & 0.908 & 0.908 & 0.908 \\
& & & & & \\
\hline
\end{tabular}

'Diets: CON: control diet (commercial growers diet with no canola meal included), CM0: control diet in which 17.5\% of soybean meal was replaced with CM; CM50: CM0 diet in which a carbohydrase multi-enzyme was added at a rate of 5\%; CM100: CM0 diet in which a carbohydrase multi-enzyme was added at a rate of 10\%; and CM150: CM0 diet in which a carbohydrase multi-enzyme was added at a rate of $15 \%$

${ }^{2} \mathrm{ME}$ : metabolizable energy 
Repeated measure analysis showed no significant $(P>0.05)$ week $\times$ diet interaction effect on AWG and FCE. However, a significant interaction effect was observed for AWFI. Table 3 indicates that diets significantly affected AWFI in weeks 8 and $9(P<0.05)$, but not in week $7(P>0.05)$. The CON diet promoted lower AWFI in week $8(186.8 \mathrm{~g})$ and week $9(193.4 \mathrm{~g})$ compared with CM100 in week $8(222.8 \mathrm{~g})$ and week 9 $(233.8 \mathrm{~g})$. In weeks 8 and 9, CON did not differ $(P>0.05)$ from CM0, CM50, and CM150 in terms of AWFI. Quail on CM100 had similar $(P>0.05)$ AWFI to CM0, CM50, and CM150. Table 3 shows that there were no significant differences in weight gain and FCE for the duration of the feeding trial.

Table 3 Weekly feed intake (g), weekly weight gain ( $\mathrm{g}$ ) and weekly feed conversion efficiency in Japanese quail fed graded levels of carbohydrase-treated canola-based diets

\begin{tabular}{|c|c|c|c|c|c|c|}
\hline & \multicolumn{5}{|c|}{${ }^{1}$ Diets } & \multirow[b]{2}{*}{${ }^{2}$ SEM } \\
\hline & CON & CMO & CM50 & CM100 & CM150 & \\
\hline \multicolumn{7}{|c|}{ Feed intake } \\
\hline Week 7 & 211.6 & 225.5 & 222.8 & 230.2 & 226.7 & 5.436 \\
\hline Week 8 & $186.8^{\mathrm{a}}$ & $213.0^{\mathrm{ab}}$ & $201.4^{\mathrm{ab}}$ & $222.8^{\mathrm{b}}$ & $198.5^{\mathrm{ab}}$ & 7.925 \\
\hline Week 9 & $193.4^{\mathrm{a}}$ & $217.1^{\mathrm{ab}}$ & $207.0^{\mathrm{ab}}$ & $233.8^{\mathrm{b}}$ & $204.2^{\mathrm{ab}}$ & 7.715 \\
\hline \multicolumn{7}{|c|}{ Weight gain } \\
\hline Week 7 & 34.16 & 37.29 & 37.59 & 37.36 & 37.43 & 3.117 \\
\hline Week 8 & 6.82 & 9.22 & 9.91 & 7.26 & 5.43 & 2.124 \\
\hline Week 9 & 8.25 & 6.06 & 4.26 & 4.89 & 6.54 & 1.472 \\
\hline \multicolumn{7}{|c|}{ Feed conversion efficiency } \\
\hline Week 7 & 0.162 & 0.167 & 0.171 & 0.163 & 0.165 & 0.015 \\
\hline Week 8 & 0.037 & 0.043 & 0.049 & 0.033 & 0.028 & 0.010 \\
\hline Week 9 & 0.042 & 0.027 & 0.021 & 0.021 & 0.032 & 0.007 \\
\hline
\end{tabular}

Diets had no significant effect on the haematological parameters of female Japanese quail, namely erythrocytes $\left(3.10-3.45 \times 10^{12} / \mathrm{L}\right)$, haemoglobin $(12.08-13.78 \mathrm{~g} / \mathrm{dL})$, haematocrit $(0.51-0.57 \mathrm{~L} / \mathrm{L})$, leucocytes $\left(34.72-50.73 \times 10^{9} / \mathrm{L}\right)$, lymphocytes $\left(27.65-43.23 \times 10^{9} / \mathrm{L}\right)$, neutrophils $\left(3.53-7.59 \times 10^{9} / \mathrm{L}\right)$ and monocytes $\left.\left(1.38-2.61 \times 10^{9} / \mathrm{L}\right)\right)$ and serum biochemical parameters, namely amylase $(300.4-512.9 \mathrm{U} / \mathrm{L})$, lipase (54.42$79.92 \mathrm{U} / \mathrm{L})$, glucose $(15.37-16.45 \mathrm{mmol} / \mathrm{L})$ and triglycerides $(0.86-1.63 \mathrm{mmol} / \mathrm{L})$.

There were no significant dietary influences on internal organs, carcass characteristics and dressing out percentage of quail $(P>0.05)$. The weights of hearts ranged from 1.98 to $2.29 \mathrm{~g}$, while those of gizzards ranged from 3.93 to $4.40 \mathrm{~g}$. Liver weights ranged from 3.95 to $4.65 \mathrm{~g}$ and the length of small intestines ranged from 51.2 to $54.4 \mathrm{~cm}$. HCW ranged from 143.2 to $164.3 \mathrm{~g}$, whereas $\mathrm{CCW}$ ranged from 141.3 to 163.3 g. Dressing-out percentage ranged from 59.3 to $69.5 \%$.

Table 4 shows that experimental diets had no significant effects on all meat quality parameters measured immediately and 24 hours post-slaughter, that is, meat $\mathrm{pH}$, temperature, lightness $\left(L^{*}\right)$, redness $\left(a^{*}\right)$, yellowness $\left(b^{*}\right)$, chroma and hue angle of Japanese quail. 
Table 4 Effects of carbohydrase-treated canola-based diets on meat quality parameters of Japanese quail immediately and 24 hours after slaughter

\begin{tabular}{|c|c|c|c|c|c|c|}
\hline & \multicolumn{5}{|c|}{${ }^{1}$ Diets } & \multirow[b]{2}{*}{${ }^{2}$ SEM } \\
\hline & CON & CMO & CM50 & CM100 & CM150 & \\
\hline \multicolumn{7}{|l|}{ At slaughter } \\
\hline Meat pH & 5.82 & 5.75 & 5.94 & 5.95 & 5.86 & 0.073 \\
\hline Temperature $\left({ }^{\circ} \mathrm{C}\right)$ & 22.57 & 23.62 & 22.38 & 23.67 & 23.42 & 0.609 \\
\hline$L^{*}$ & 48.13 & 48.36 & 47.11 & 47.47 & 46.81 & 0.861 \\
\hline$a^{*}$ & 1.33 & 1.13 & 1.27 & 1.46 & 1.32 & 0.183 \\
\hline$b^{*}$ & 9.10 & 9.71 & 8.87 & 8.74 & 9.65 & 0.396 \\
\hline Chroma & 9.20 & 9.79 & 8.82 & 8.87 & 9.7 & 0.403 \\
\hline Hue angle & 1.3 & 1.46 & 1.42 & 1.41 & 1.44 & 0.018 \\
\hline \multicolumn{7}{|l|}{$24 \mathrm{~h}$ post-slaughter } \\
\hline Meat pH & 6.9 & 6.65 & 6.38 & 6.49 & 6.59 & 0.125 \\
\hline Temperature $\left({ }^{\circ} \mathrm{C}\right)$ & 10.61 & 11.32 & 10.37 & 10.51 & 10.52 & 0.319 \\
\hline$L^{*}$ & 47.27 & 47.77 & 47.5 & 47.23 & 46.61 & 0.513 \\
\hline$a^{*}$ & 3.74 & 2.47 & 3.34 & 3.81 & 3.47 & 0.348 \\
\hline$b^{*}$ & 11.87 & 11.36 & 11.73 & 11.63 & 11.68 & 0.302 \\
\hline Chroma & 12.45 & 11.66 & 12.21 & 12.26 & 12.20 & 0.348 \\
\hline Hue angle & 1.27 & 1.36 & 1.29 & 1.26 & 1.28 & 0.025 \\
\hline
\end{tabular}

Experimental diets had no influence $(P>0.05)$ on cooking losses and peak positive force (Figure 1). Cooking losses ranged from 23.60 to $25.70 \%$, and peak positive force ranged from 5.15 to $6.80 \mathrm{~N}$.

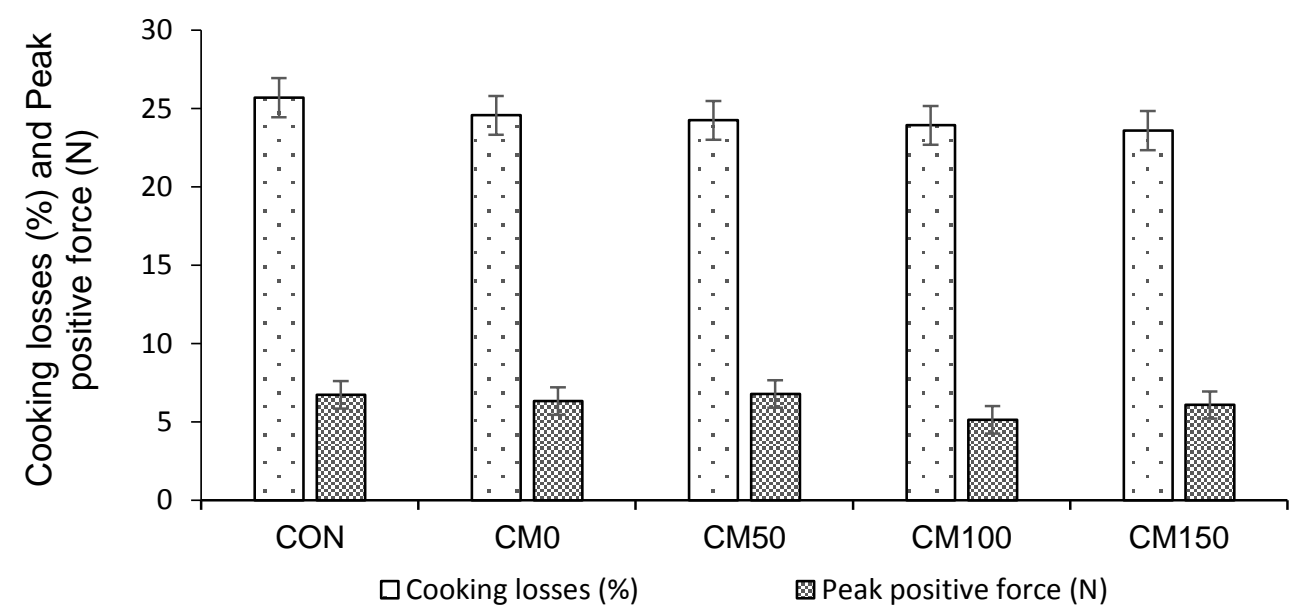

Figure 1 Cooking losses (\%) and peak positive force $(\mathrm{N})$ of Japanese quail as influenced by diets (CON: control diet (commercial growers diet with no canola meal included), CM0: control diet in which 17.5\% of soybean meal was replaced with CM; CM50: CM0 diet in which a carbohydrase multi-enzyme was added at a rate of 5\%; CM100: CM0 diet in which a carbohydrase multi-enzyme was added at a rate of $10 \%$; and CM150: CM0 diet in which a carbohydrase multi-enzyme was added at a rate of 15\%) 


\section{Discussion}

According to Wickramasuriya et al. (2015), CM has higher methionine content than SBM and this explains why the inclusion of CM in quail diets in this study increased methionine levels, which is the major limiting amino acid in birds (Canola Council of Canada, 2009). Repeated measure analyses revealed a significant diet $\times$ week interaction effect on average weekly feed intake, signifying that the influence of diet on feed intake changed as the quail grew older. In week 8 and week 9, the control diet promoted lower AWFI compared with CM100, suggesting a compensatory feeding by the quail owing to dilution of nutrient concentration, which could have affected feed intake. Since the inclusion level of CM was $17.5 \%$ in place of soybean, it is likely that the NSP content in the canola would have induced a decrease in feed intake. However, the addition of the carbohydrases was intended to degrade the NSP and thus facilitate the absorbance of nutrients and improve weight gain. According to Walugembe et al. (2014), feeding fibrous diets in poultry tend to increase feed intake as a way of compensating for the reduced nutrient concentration in feed. However, according to Mnisi \& Mlambo (2017), dietary inclusion of canola beyond $125 \mathrm{~g} / \mathrm{kg}$ reduces feed intake and could compromise the performance of female Japanese quail.

The application of exogenous carbohydrase enzymes has been reported to improve feed utilization, nutrient digestibility and weight gain in birds fed fibrous diets (Gracia et al., 2003; Adeola \& Bedford, 2004; Romero et al., 2013). Single enzymes such as xylanases and glucanases are mostly incorporated in poultry diets, representing more than $80 \%$ of the global carbohydrase market (Adeola \& Cowieson, 2011). However, in this study, treating the canola-based diets did not improve feed intake, weight gain, or FCE, which agreed with the findings of Simbaya et al. (1996), Meng \& Slominski (2005), and Mushtaq et al. (2007), who reported no effect of multi-carbohydrase enzyme in chickens fed CM-based diets. Additionally, Jia et al. (2012) and Radfar et al. (2017) found no improvement in broilers fed diets containing $150 \mathrm{~g} / \mathrm{kg}$ of CM supplemented with carbohydrase enzyme. The differences in the mode of action and performance of the carbohydrases could be attributed to variations in application methods and the activities of the enzymes that were used in various studies (Yuan et al., 2008).

Experimental diets had no significant impact on haematological and serum biochemical parameters of female Japanese quail, which fell within the normal ranges for quail (Ali et al., 2012). This suggests that carbohydrase treatment of quail diets did not influence the physiological and pathophysiological status of the birds. It was expected that supplementation with carbohydrase would reduce the activity of pancreatic digestive enzymes, which would be manifested partly as lower serum amylase activity. Triglycerides values were also within the normal ranges for quail, indicating that there were no diet-induced modifications in the energy and fat metabolism of quail. Carbohydrase-treated diets did not affect the sizes of internal organs, carcass characteristics, $\mathrm{pH}$, temperature, and colour of the meat, which were similar to those of quail fed an untreated CM-based diet. These findings are in agreement with Gracia et al. (2003), who observed no effect of carbohydrase single enzyme supplementation on relative weights of broiler organs. Longer small intestines in quail offered CM-based diets have been observed by Mnisi and Mlambo (2017), and could be the result of an adaptive mechanism to deal with the increased amounts of fibre for efficient digestion and absorption of nutrients. Experimental diets had no significant influence on cooking losses and peak positive force values of female Japanese quail, suggesting that application of carbohydrases did not improve meat quality traits.

\section{Conclusions}

The current study revealed that carbohydrase-treated CM-based diets promoted similar performances in terms of growth response, health status and meat quality traits to the untreated CM-based diet. It was therefore concluded that the dietary inclusion of an exogenous carbohydrase multi-enzyme did not improve the utilization of a CM-based quail diet. However, there is a possibility that utilization of higher canola levels can be enabled through other types of enzymes targeting or countering various antinutritional factors.

\section{Acknowledgements}

The authors express their gratitude for financial support from the Health and Welfare Sector Education and Training Authority towards this study. Miss Cebisa Kumanda, North-West University technician, is hereby acknowledged.

\section{Conflict of Interest Declaration}

The authors declare that they have no conflict of interests.

\section{Authors' Contributions}

CMM and VM designed the study. CCM, KGP and TBM conducted the feeding trial and data collection. CMM and VM analysed the data statistically and wrote the paper. 


\section{References}

Adeola, O. \& Bedford, M.R., 2004. Exogenous dietary xylanase ameliorates viscosity-induced anti-nutritional effects in wheat-based diets for White Pekin ducks (Anas platyrinchos domesticus). Br. J. Nutr. 92(1), 87-94.

Adeola, O. \& Cowieson, A.J., 2011. Opportunities and challenges in using exogenous enzymes to improve nonruminant animal production. J. Anim. Sci. 89(10), 3189-3218.

AgriLASA (Agri Laboratory Association of Southern Africa), 1998. Feed and plant analysis methods. AgriLASA, Pretoria, South Africa.

Ahmad, G., Mushtaq, T., Mirza, M.A. \& Ahmed, Z., 2007. Comparative bioefficacy of lysine from L-Lysine hydrochloride or L-Lysine sulfate in basal diets containing graded levels of canola meal for female broiler chickens. Poult. Sci. 86(3), 525-530.

Ali, M.A., Hmar, L., Devi, L.I., Prava, M., Lallianchhunga, M.C. \& Tolenkhomba, T.C., 2012. Effect of age on the haematological and biochemical profile of Japanese quail (Coturnix coturnix japonica). Int. Multidisciplinary Res. J. 2(8), 32-35.

AOAC, 2005. Official methods of analysis of AOAC International (18th ed.). Association of Official Analytical Chemists, Arlington, VA, USA.

Beski, R., Sleman, A., Swick, S.M. \& lji, P.A., 2015. Specialized protein products in broiler chicken nutrition: A review. Anim. Nutr. 1(2), 47-53.

Buetow, B.S., Treuting, P.M. \& Van Hoosier, G.L., 1999. The hamster. In: W.F. Loeb \& F.W. Quimby (eds.). The clinical chemistry of laboratory animals. Taylor \& Francis, Philadelphia. pp. 49-63.

Campbell, G.L., \& Bedford, M.R., 1992. Enzyme applications for monogastric feeds: A review. Can. J. Anim. Sci. 72(3), 449-466.

Canola Council of Canada, 2009. Canola meal feed industry guide, 2009, Canola Council of Canada, Winnipeg, MB, Canada.

Choct, M., 2006. Enzymes for the feed industry: Past, present and future. World's Poult. Sci. J. 62(1), 5-16.

Cowieson, A.J. \& Bedford, M.R., 2009. The effect of phytase and carbohydrase on ileal amino acid digestibility in monogastric diets: Complementary mode of action? World's Poult. Sci. J. 65(4), 609-624.

Cowieson, A.J., 2005. Factors that affect the nutritional value of maize for broilers. Anim. Feed Sci. Technol. 119(3-4), 293-305.

Dauda, G. Momoh, O.M., Dim, N.I. \& Ogah, D. M., 2014. Growth, production and reproductive performance of Japanese quails (Coturnix coturnix japonica) in humid environment. Egypt Poult. Sci. 34(2), 381-395.

Deka, K. \& Borah, J., 2008. Haematological and biochemical changes in Japanese quails Coturnix coturnix japonica and chickens due to Ascaridia galli infection. Int. J. Poult. Sci. 7(7), 704-710.

Elagib, H.A.A., El-Amin, W.I.A., Elamin, K.M. \& Malik, H.E.E., 2013. Effect of dietary garlic (Allium sativum) supplementation as feed additive on broiler performance and blood profile. J. Anim. Sci. Adv. 3(2), 58-64.

Fernández, M., Obeda, J.F. \& Briones, A.I., 2000. Typing of non-Saccharomyces yeasts with enzymatic activities of interest in wine-making. Int. J. Food Microbiol. 59(1-2), 29-36.

Gao, F., Jiang, Y., Zhou, G.H. \& Han, Z.K., 2008. The effects of xylanase supplementation on performance, characteristics of the gastrointestinal tract, blood parameters and gut microflora in broilers fed on wheat-based diets. Anim. Feed Sci. Technol. 142(1-2), 173-184.

Gracia, M.I., Aranibar, M., Lazaro, R., Medel, P. \& Mateos, G.G., 2003. Alpha-amylase supplementation of broiler diets based on corn. Poult. Sci. 82(3), 436-442.

Jia, W., Mikulski, D., Rogiewicz, A., Zdunc'ızyk, Z., Jankowski, J. \& Slominski, B.A., 2012. Low-fiber canola. Part 2. Nutritive value of the meal. J. Agric. Food Chem. 60(50), 12231-12237.

Kabir, S.M.L., Rahman, M.M., Rahman, M.B., Rahman, M.M. \& Ahmed, S.U., 2004. The dynamics of probiotics on growth performance and immune response in broilers. Int. J. Poult. Sci. 3(5), 361-364.

Khajali, F. \& Slominski, B.A., 2012. Factors that affect the nutritive value of canola meal for poultry. A review. Poult. Sci. 91(10), 2564-2575.

Meng, X. \& Slominski, B.A., 2005. Nutritive values of corn, soybean meal, canola meal, and peas for broiler chickens as affected by a multi-carbohydrases preparation of cell wall degrading enzymes. Poult. Sci. 84(8), 1242-1251.

Min, Y., Wang, Z., Coto, C., Yan, F., Cerrate, S., Liu, F. \& Waldroup, W., 2011. Evaluation of canola meal from biodiesel production as a feed ingredient for broilers. Int. J. Poult. Sci. 10(10), 782-785.

Minvielle, F., 2004. The future of Japanese quail for research and production. World Poult. Sci. J. 60, 500-506.

Mnisi, C.M. \& Mlambo, V., 2017. Growth performance, haematology, serum biochemistry and meat quality characteristics of Japanese quails (Coturnix coturnix japonica) fed canola meal-based diets. Anim. Nutr. DOI: 10.1016/j.aninu.2017.08.011

Mnisi, C.M., Matshogo, T.B., Van Niekerk, R.F. \& Mlambo, V., 2017. Growth performance, haematological and serum biochemical parameters and meat quality characteristics of male Japanese quails fed a Lippia javanica-based diet. S. Afr. J. Anim. Sci. 47(5), 661-671.

Mushtaq, T., Sarwar, M., Ahmad, T., Mirza, M.A., Nawaz, H., Mushtaq, M.M. \& Noreen, U., 2007. Influence of canola meal-based diets supplemented with exogenous enzyme and digestible lysine on performance digestibility, carcass, and immunity responses of broiler chickens. Poult. Sci. 86(10), 2144-2151.

Naseem, M.Z., Khan, S.H. \& Yousaf, M., 2006. Effect of feeding various levels of canola meal on the performance of broiler chicks. J. Anim. PI. Sci. 16 (3-4), 78-82.

Priolo, A., Micol, D., Agabriel, J., Prache, S. \& Dransfield, E., 2002. Effect of grass or concentrate feeding systems on lamb carcass and meat quality. Meat Sci. 62(2), 179-185. 
Puspamitra, S., Mohanty, P.K. \& Mallik, B.K., 2014. Haematological analyses of Japanese quail (Coturnix coturnix japonica) at different stages of growth. Int. Res. J. Biol. Sci. 3(11), 51-53.

Radfar, M., Rogiewicz, A. \& Slominski, B.A., 2017. Chemical composition and nutritive value of canola-quality Brassica juncea meal for poultry and the effect of enzyme supplementation. Anim. Feed Sci. Technol. 225, 97-108.

Ravindran, V., Hew, L.I., Ravindran, G., Bryden, W.L., 2005. Apparent ileal digestibility of amino acids in dietary ingredients for broiler chickens. Anim. Sci. 81, 85-97.

Romero, L.F., Parsons, C.M., Utterback, P.L., Plumstead, P.W. \& Ravindran, V., 2013. Comparative effects of dietary carbohydrases without or with protease on the ileal digestibility of energy and amino acids and AMEn in young broilers. Anim. Feed Sci. Technol. 181(1-4), 35-44.

SAS, 2010. Users guide: Statistics. Version 9.3. SAS Institute, Cary, NC, USA.

Simbaya, J., Slominski, B.A., Guenter, W., Morgan, A. \& Campbell, L.D., 1996. The effects of protease and carbohydrase supplementation on the nutritive value of canola meal for poultry: In vitro and in vivo studies. Anim. Feed. Sci. Technol. 61(1-4), 219-234.

South African Bureau of Standards, 2008. South African National Standard: The care and use of animals for scientific purposes, 1st ed. Pretoria, South Africa. pp. 232.

Stanford, K., Aalhus, J.L., Dugan, M.E.R., Wallins, G.L., Sharma, R. \& McAllister, T.A., 2003. Effects of feeding transgenic canola on apparent digestibility, growth performance and carcass characteristics of lambs. Can. J. Anim. Sci. 83(2), 299-305.

Vagadia, B.H., Vanga S.K. \& Raghavan, V., 2017. Inactivation methods of soybean trypsin inhibitor - A review. Trends Food Sci. Technol. 64, 115-125.

Van Soest, P.J., Robertson, J.B. \& Lewis, B.A., 1991. Methods for dietary fiber, neutral detergent fiber, and non-starch polysaccharides in relation to animal nutrition. J. Dairy Sci. 74(10), 3583-3597.

Walugembe, M., Rothschild, M.F. \& Persia, M.E., 2014. Effects of high fiber ingredients on the performance, metabolizable energy and fiber digestibility of broiler and layer chicks. Anim. Feed Sci. Technol. 188, 46 - 52.

Washington, I.M. \& Van Hoosier, G., 2012. Clinical biochemistry and hematology. University of Washington, Seattle, WA, USA. 59-91.

Wickramasuriya, S.S., Yi, Y.J., Yoo, J., Kang, N.K. \& Heo, J.M., 2015. A review of canola meal as an alternative feed ingredient for ducks. J. Anim. Sci. Technol. 57, 29.

Woyengo, T.A., Beltranena, E. \& Zijlstra, R.T., 2014. Nonruminant Nutrition Symposium: Controlling feed cost by including alternative ingredients into pig diets: A review. J. Anim. Sci. 92(4), 1293-305.

Yuan, J., Yao, J., Yang, F., Yang, X., Wan, X., Han, J., Wang, Y., Chen, X., Liu, Y., Zhou, Z., Zhou N. \& Feng, X., 2008. Effects of supplementing different levels of a commercial enzyme complex on performance, nutrient availability, enzyme activity and gut morphology of broilers. Asian-Aust. J. Anim. Sci. 21(5), 692-700. 